\title{
Knivsberg
}

\section{Den tysksindede befolknings Fest- og Turnplads i Sønderjylland ca. 1920-1945}

\section{Af Jørn Hansen}

Ikke langt fra Aabenraa med en storslået udsigt over Genner bugt ligger Knivsbjerg eller »Knivsberg « som det hedder på tysk. Afhængig af om man forholder sig til stedet ud fra en dansk eller tysk synsvinkel vil man betegne regionen, hvor bjerget er beliggende, som Sønderjylland eller Nordschleswig. Enige er man dog om, at lokaliteten er placeret i Slesvig, hvis historie er knyttet til dobbelthertugdømmet SlesvigHolstens omskiftelige relationer til hen- holdsvis den danske og den tyske stat. Denne komplicerede historie danner baggrunden for, at der siden nationalstaternes grundlæggelse i forrige århundrede har været tale om danske og tyske mindretal i grænseområdet mellem Danmark og Tyskland. Kort fortalt var Slesvig-Holsten frem til 1864 forbundet med det danske kongehus. I 1848 rejste en frihedsbevægelse i Slesvig-Holsten sig i kølvandet på Martsopstanden mod den daværende danske ene-

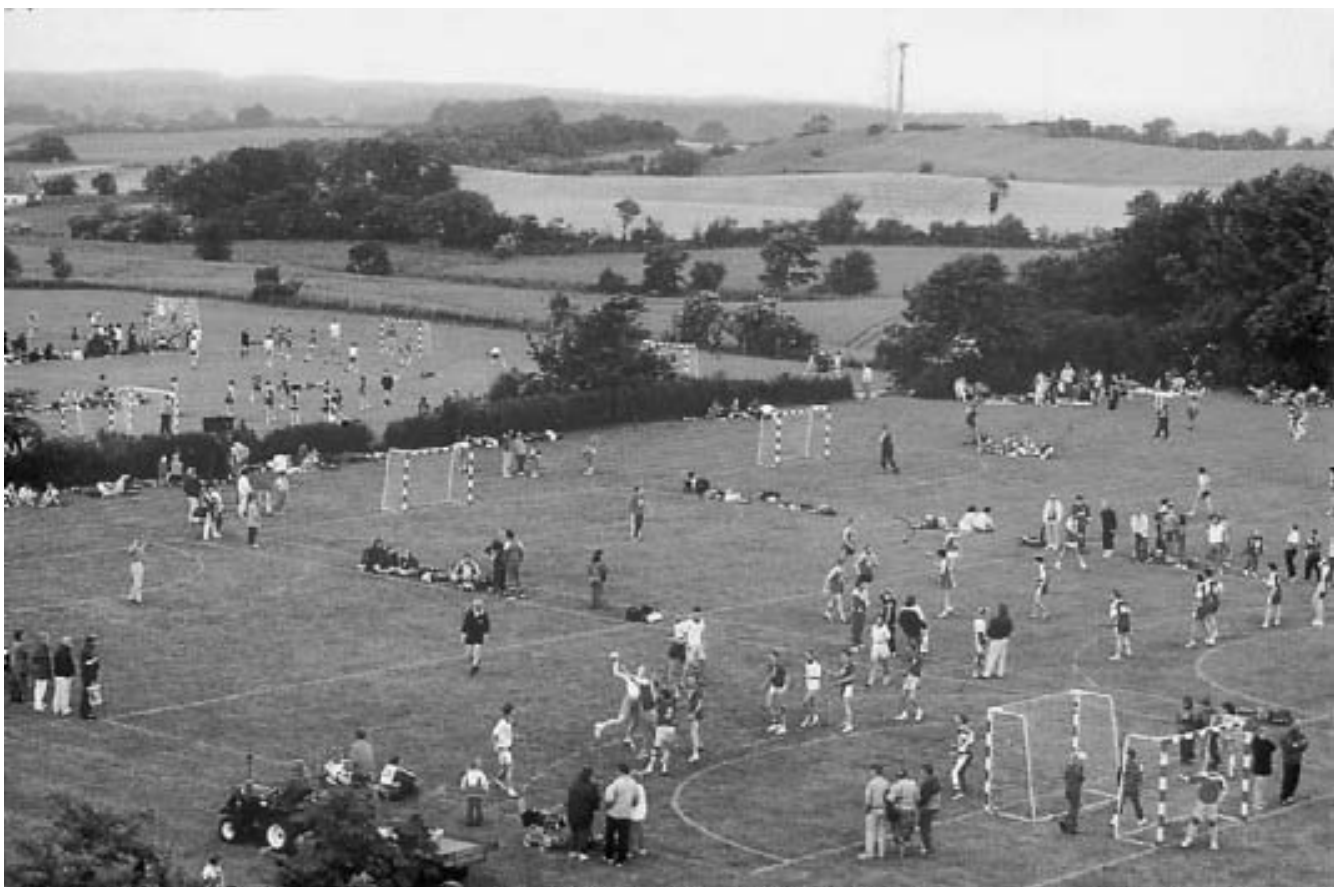

Knivsbjergsfesten 1992 (foto fra Der Knivsberg, 1994). 
vælde og banede vejen for, at den danske stat i 1864 måtte afgive Slesvig-Holsten til Preussen. Efter en folkeafstemning i 1920 blev den nuværende grænse mellem Tyskland og Danmark etableret, og Knivsbjerg blev fra da af en lokalitet i Danmark. I perioden efter 1864 medvirkede turnbevægelsen i Slesvig aktivt til at befæste tysk ideologi over for de områder i Slesvig, hvor danskheden stod stærkest. ${ }^{1}$

\section{Turnbevagelsen og Knivsbergfesten}

Fra 1866 efter Preussens sejr over Østrig fik Slesvig reelt status som en preussisk provins, og der blev overensstemmelse mellem ideologien i turnbevægelsen i Slesvig og statsmagten for det tyske rige. Danmark og dansksindede slesvigere håbede på, at datidens stormagter kunne bringe Slesvig tilbage til Danmark. Efter Napoleon III's nederlag ved Sedan i 1870 var der dog intet reelt grundlag for dette håb, og dansksindede slesvigere måtte tilpasse sig tingenes tilstand og føre en længerevarende sindelagskamp mod tysksindede slesvigere. Sejren ved Sedan blev ligesom sejren ved Leipzig i 1813 et symbol for turnbevægelsen, og femårsdagen for Sedan-slaget blev en passende anledning til, at turnbevægelsen i Flensborg kunne indvie en foreningsfane med de fire gange $»$ F $\ll$ - Frisch, Fromm, Fröhlich, Frei - som udtryk for turnernes valgsprog. Samme år vedtog Flensburger Turnerschaft at gøre den årlige march til Oeversee til en særlig turnerbegivenhed. Ved slaget ved Oeversee i februar 1864 havde preussiske og østrigske styrker tilføjet danskerne et afgørende nederlag. ${ }^{2}$

Turnbevægelsen bredte sig under aktiv medvirken fra Flensburger Turnerschaft til tre af de større nordslesviske byer Tønder, Aabenraa og Haderslev. I disse byer dannede tysksindede turnforeninger, der meldte sig ind $\mathrm{i} »$ Deutscher Turnerschaft $\ll{ }^{3}$ På denne måde kom turnbevægelse til at indgå som en vigtig bestanddel i bestræbelserne på at »fortyske« Nordslesvig.

I perioden fra 1864 til midt i 1880'erne udbredte og stabiliserede det tyske foreningsliv sig i Flensborg-området. Det danske sindelag, der i 1864 havde stået stærkt i dette område, gik tilbage i takt med byens modernisering og indførelsen af tysk som obligatorisk skolesprog. Nordslesvig, hvor der i 1880 var blevet dannet en dansk sprogforening og i 1888 en dansk vælgerforening, blev nu hjemstedet for de dansktyske modsætninger. Fra slutningen af 1880'erne ønskede regeringen i Berlin med Bismarck i spidsen dette område germaniseret; i 1888 indførtes tysk som skolesprog, og man krævede, at alle prædikener skulle foregå på tysk. ${ }^{4}$

Med det formål at fremme tyskheden kulturelt og politisk dannedes i 1890 »Deutscher Verein für das nördliche Schleswig «. Foreningen, der i 1909 havde 59 lokalafdelinger, optrådte som pressionsgruppe over for regeringsinstanserne; den var domineret af tyske embedsmænd og knyttede sig til det højreradikale Altyske Forbund. Da E. M. Köller i 1897 blev overpræsident i Slesvig-Holsten, fik den tyske forening sit krav om en hårdhændet behandling af dansksindede opfyldt. Det mest anvendte våben var udvisning af uønskede personer, der ikke havde tysk statsborgerskab - en udvisningsgrund kunne være organisering af masseudflugter til Danmark. ${ }^{5} »$ Deutscher Verein für das nördliche Schleswig « stod bag »der Knivsberggesellschaft« der i 1893 købte Knivsbjerg ved Genner ikke langt fra Aabenraa. Stedet skulle, som modstykke til 
danskernes »Skamlingsbanke«, benyttes til at afholde folkefester for at ære den tyske stat.

Skamlingsbanken havde fra 1843 været hjemstedet for de dansksindede Nordslesvigeres årlige nationale fest, og stedet var frem til grænsedragningen i 1864, hvor Kongeåen blev grænsedeler, Sydjyllands højeste punkt. I en avis-omtale af Knivsbjergfesten fra 1902 henvistes direkte til, hvorledes man:

»...verkündeten bis weit ins Land hinein, bis weit über die Königsau - (mod Skamlingsbanken) - daß deutsche Männer und Frauen in deutschem Lande ihre deutsche Volksfest feierten «. ${ }^{6}$

På Knivsberg, der efter grænsedelingen i 1864 var det højeste punkt i landsdelen, afholdtes i 1894 den første fest med ca. 45.000 deltagere. Hovedtaler var den såkaldte »Vater des Knivsberges « Reichstagsabgeordneten Jebsen, der direkte henvendte sig til de dansksindede:

»Heute können die sogen. »Südjüten« zum ersten Male vom Knivsberge die deutsche Fahne wehen sehen, das Banner wird auch diese daran mahnen, daß sie deutsche Untertahnen sind «.?

I 1896 indgik i Knivsbjergfesten for første gang også en idræts- og turnfest med deltagelse af studenter fra Kiel, skoleelever fra Haderslev, turnere fra Flensborg og de Nordslesvigske foreninger. Festen blev en fast årlig begivenhed, hvor især Flensborgs Turnerforeninger aktivt deltog »in Turnertreue und mit Turnerdank an den sportlichen Wettkämpfen und den politischen Kundgebungen $\ll^{8}$ Med tiden blev Knivsbjerg udbygget med pavillion, turn- og sportsplads samt ungdomsherberg. I mod- sætning til den årlige danske nationale manifestation ved Skamlingsbanken blev idræt i form af turnen, folkelige lege og med tiden boldspil en integreret del af Knivsbjergfesten. Dette skulle vise sig at være vigtig i forbindelse med de politiske forandringer, der de næste 50 overgik den tysksindede befolkning i området, og hvor idrætten kom til at udgøre et vigtigt måske det vigtigste element for kontinuiteten for »tyskheden .

Samme år som turnbevægelsen første gang deltog i Knivsbjergfesten, lagde man den første sten til Knivsbjergtårnet, og i 1901 kunne man på årsdagen for den første tyske sejr i 1870 indvie et såkaldt »Vaterlands-Monument «. Hele anlægget var udformet som et ældgammelt kultsted med 12 klippesøjler, der dannede kreds om et tårn af granitsten. På tårnets sokkel stod turnbevægelsens slagord fra Vormärz-tiden »Jungs holt fast «. Ved tårnets fire sider var der offeraltre, og i selve tårnet stod en $7 \mathrm{~m}$. høj kobberstatue af Bismarck med rigssværd og rigskrone som attributter. Under Bismarck, der fra sin plads kunne skue over store dele af grænselandet, stod indskriften »Up ewig ungedelt«, som udtryk for Slesvig og Holstens evige forbundethed og i denne sammenhæng tilknytning til det tyske rige. ${ }^{9}$

Såvel festerne på Skamlingsbanken som på Knivsbjerg skriver sig ind i traditionen for nationale identitetsskabende manifestationer, hvor for tysk kulturs vedkommende Wartburgerfesten i 1817 og Hambacher Festen i 1832 kan fremdrages som skoledannende eksempler, medens startskuddet i Danmark gik med den første Himmelbjergsfest i 1838, der fem år senere udgjorde inspirationen til den første Skamlingsbankefest. ${ }^{10}$

Fra 1897 forløb Knivsbjergfesten efter et fast mønster. Tidspunktet var med få 


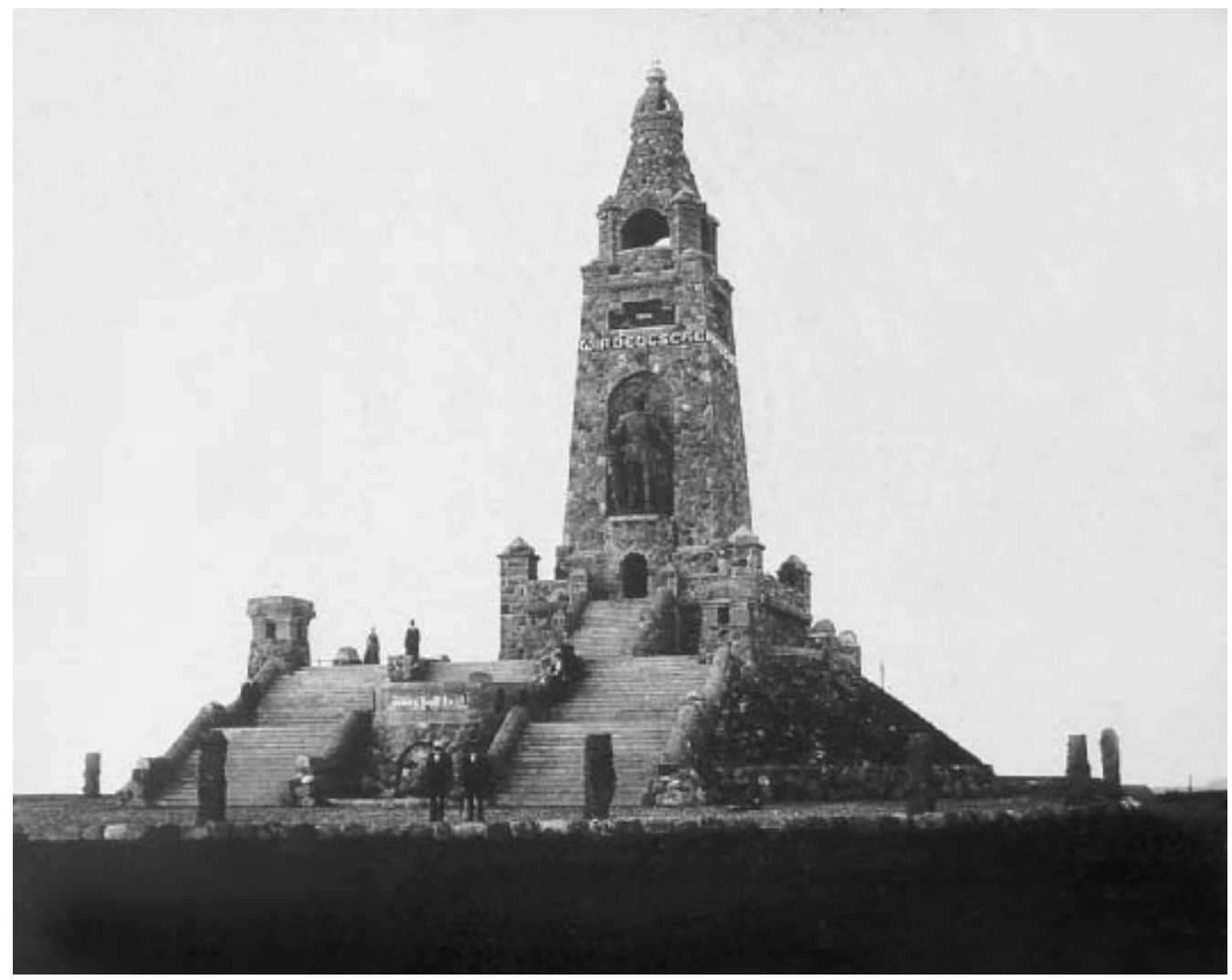

Bismarckmindesmarket fotograferet 1905 (fra Der Knivsberg, 1994).

undtagelser altid i juni måned tæt på midsommer, ofte antog festen også karakter af midsommerfest. Den 20 juni 1897 så programmet med start klokken 16 ud som følger:

1. Reichtagsabgeordneter M. Jebsen: Hoch auf Se. Majestät den Kaiser. »Heil Dir Im Siegekranz «

2. Männergesang

3. Director Dr. Spanuth-Sonderburg: Das Deutsche Reich.

»Deutschland, Deutschland über alles«

4. Männergesang

5. Rektor Petersen-Lügumkloster: Fürst Bismarck.

»Schleswig-Holstein Meerumschlungen«
6. 51/2 Uhr: Gerätturnen, Faustball, Wettübungen

(Steinstosen und Stabweitspringen)

7. 8. Uhr: Ball im zwei Zelten

8. 10. Uhr: Großes Feuerwerk ${ }^{11}$

Efter 1. verdenskrig var man fra tysk side klar over, at den kommende afstemning i Slesvig sandsynligvis ville give dansk flertal i Nordslesvig, og man frygtede for monumentets sikkerhed under et dansk styre. Derfor besluttede man sig for at fjerne Bismarck-statuen og flyttede den efter nogle år til Aschberg ved Hytten Bjerge (Hüttener Berge) sydøst for Slesvig, hvor man ligeledes indrettede et mødested med ungdomsherberg og sportsanlæg. 


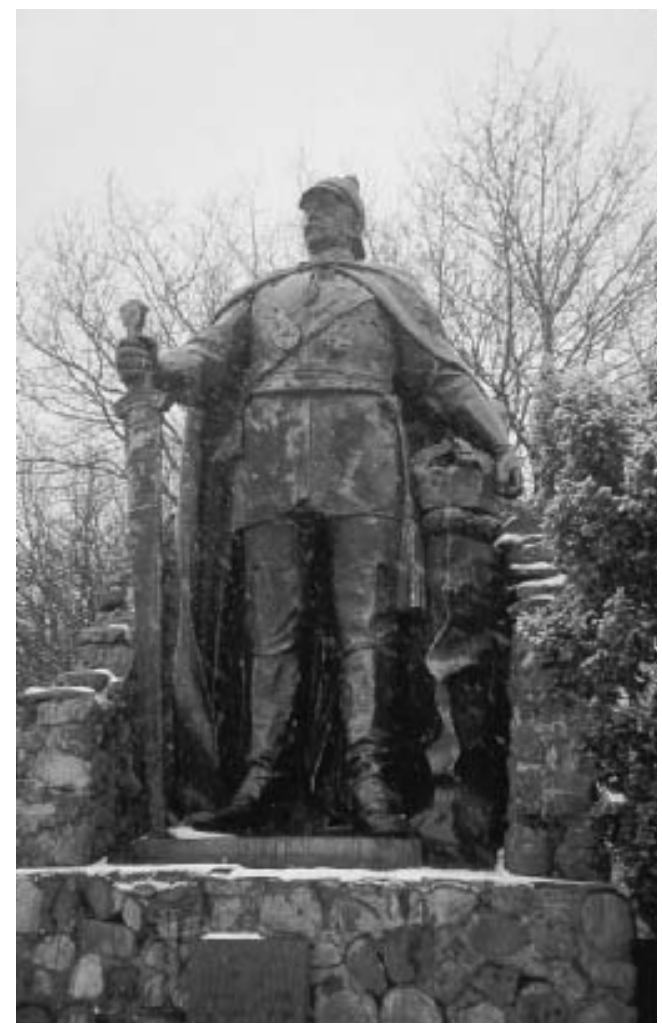

Bismarck uden tårn anno 1999 ved Hüttener Berge sydøst for Slesvig (foto Jørn Hansen).

Knivsbjergfesten i 1919 var præget af bevidstheden om, at det givetvis ville blive den sidste under tysk herredømme og blev derfor ligesåmeget en demonstration for hele den Slesvig-Holstenske tanke - »Up ewig ungedelt «. Karakteristisk var det ifølge avisreferaterne vedrørende »Abschied von Deutscher Nordmark «, at deltagerne hovedsagelig bestod af Kieler-Studenter og Slesvig-Holstenske Turnere - i historisk Jahndragt med fanen fra 1848 - de tysksindede nordslesvigere glimrede ved deres fravær.
Berlins kommentar til festen i 1919 var entydig:

»Das Fest auf dem Knivsberg ist ... eine Provokation der Dänen, die man aus Grunden politischer Klugheit hätte unterlassen sollen. Das Denkmal ist als Dänentrutz errichtet, in der Gegend wohnen ausser Schullehrern und Gendarmen keine Deutschen und die Stätte war ein Tummelplatz chauvinistische Bestrebungen ${ }^{12}$

Således lød det fra den nye demokratiske republik. Det var rigtigt, at Nordslesvig overvejende var dansksindet, at Knivsbjergfesterne hidtil havde været udtryk for tysk chauvinisme »Für Kaiser und Vaterland «, men der eksisterede fortsat et tysksindet mindretal nord for den i 1920 dragne grænse, og ungdommen kunne gennem idrætten medvirke til at holde liv i Knivsbjergfesten - først i form af »volklichen Aufbau « senere efter 1933 i form af fornyet tysk chauvinisme og revanchisme. ${ }^{13}$

\section{Volklichen Aufbau}

Deutscher Jugendverband

Nordschleswig - Knivsbjerg

frem til 1932

Ved afstemningen i 1920 stemte i Nordslesvig 75\% for Danmark og 25\% for Tyskland. Stærkest stod tyskheden i de områder, der kom til at ligge lige op af den nye grænse, hvor der enkelte steder som i Tønder og Højer var absolut tysk flertal. Den tysksindede befolkning skulle til at organisere sig under de nye forhold, og det var ungdomsforeningerne, der var blandt de første til at udfylde det tomrum, der var opstået efter afstemningen. Fra tiden før 
1920 overlevede blot nogle få Wandervogelgrupper, men allerede i 1920 blev det første Jugendbund oprettet i Nordborg på Als. Hurtigt fulgte flere deriblandt et i Løjt, hvor den under 1. verdenskrig sårede Oberleutnant Peter Larsen Barsmark var blandt initiativtagerne. Formålet med foreningen var at arbejde for tyskhedens bevarelse og fremgang, samt søge at gennemtrænge ungdommen $\mathrm{i}$ alle samfundslag og erhverv med tysk ånd. Midlet var folkelig selvhjælp, politisk opdragelse og statsborgerlig oplysning. ${ }^{14}$

Ungdomsforeningerne var dog ikke helt alene om at udfylde tomrummet efter 1920. Der var en selvfølgelig fødelinie fra det tyske mindretals skoler $\mathrm{i}$ form af »Deutsche Privatschulen« og »Deutsche Kommunalschulen in Nordschleswig « til de nydannede ungdomsforeninger. Tilsammen havde det tyske mindretals skoler i 1921 godt 3.000 elever, og mange af skolelærerne kom til at udgøre bindeleddet til foreningslivet. ${ }^{15}$

Allerede i 1921 besluttede en række Nordschleswische Jugendbünde sig for at fastholde Knivsbjergfesterne. Og i juni afholdtes en, hvad angår deltagerantallet, forholdsvis beskeden »Spiel- und Sportfest« med følgende aktiviteter: Schlag-, Faust- und Tamburinball og volkstümlichen Wettübungen. Derudover var der musik ved Pfadfinderkorps og folkedans ved en gruppe unge Wandervögel. Ved den efterfølgende prisuddeling satte taleren, der i Apenrader Tageblatt er refereret uden navn, idrætten ind $\mathrm{i}$ en større sammenhæng:

"Aber einen anderen Kampf gilt es heute zu führen, den Kampf ums Dasein, den Kampf um unserer Existenz ... Wir Spielen nämlich nicht nur, um den Körper zu stählen, wir wissen, daß diese
Volksspiele, wie wir sie treiben, auch unmittelbar Geisterkräfte wachrufen «. ${ }^{16}$

I sommeren 1921 afholdt det tyske ungdomsforbund et første årsmøde i Rødekro, og ved denne lejlighed blev der under navnet »Deutsche Jugendbund « oprettet en hovedorganisation. Senere kom organisationen til at hedde »Deutsche Jugendverband Nordschleswig «. På samme måde som Wählerverein og Schulverein blev Jugendverband inddelt $i$ fire kredsafdelinger, der hver var repræsenteret med en person i et fælles forretningsudvalg på i alt 7 medlemmer med pastor Johannes Schmidt-Wodder som formand. Målet for foreningen var, ud over at puste liv i Knivsbjergfesterne, at være bærere af tysk liv og ære over for det danske folk. Dette skulle ske ved at værne og uddybe tysk sæd og skik. ${ }^{17}$ De første år oplevede ungdomsforeningerne en hurtig vækst, for i midten af 1920'erne at have nået et forholdsvist stabilt leje, som man af tabellen over medlemssammensætningen fra 1928 kan få et godt indtryk af. ${ }^{18}$

I 1922 var det tyske mindretal så velorganiseret og faststømret, at det begyndte at udgive tidsskriftet $\gg N o r d s c h l e s w i g$. Beitrage zur volklichen Aufbau«. I det første hefte fastlagde man en strategi, der i paroleform også gav udtryk for opfattelsen af den situation, mindretallet i 1920 var blevet bragt i. Pastor Sckmidt-Wodder, der blev det tyske mindretals repræsentant i folketinget, skrev således:

»Selbstbestimmung, als Betrug an unserm Volk gedacht, in Schwäche von uns ergriffen, soll, als Waffe kraftvoll aufgenommen, uns die Tore der Zukunft öffne ${ }^{19}$

I hefte nummer to fulgte en længere omtale af betydningen af Knivsbjerg-festerne 
Tabel 1. Deutscher Jugendverband Nordschleswig:

Tilsluttede foreninger og medlemmer pr. 1. oktober 1928.

\begin{tabular}{|c|c|c|c|c|}
\hline & $\mathrm{B} \varnothing \mathrm{rn}$ & u. 20 år & Voksne & I alt \\
\hline \multicolumn{5}{|l|}{ Kreisjugendverband Apenrade } \\
\hline 1. Jugendbund, Østerterp & & 14 & 26 & 40 \\
\hline 2. Jugendbund, Hovslund & & & 12 & 12 \\
\hline 3. Jugendbund, Løjt & & 32 & 5 & 37 \\
\hline 4. Jugendbund, Uge & 30 & 5 & 10 & 45 \\
\hline 5. Jugendbund, Holbøl & & 8 & 11 & 19 \\
\hline 6. Jugendbund, Bjerndrup ${ }^{1}$ & 34 & 11 & 7 & 52 \\
\hline 7. Jugendbund, Rødekro ${ }^{1}$ & & 20 & 11 & 31 \\
\hline 8. Pfadfindercorps, Aabenraa & 60 & 40 & 15 & 115 \\
\hline \multirow[t]{2}{*}{ 9. Sportsverein, Rinkenæs ${ }^{2}$} & $?$ & $?$ & $?$ & $?$ \\
\hline & 124 & 130 & 97 & 351 \\
\hline \multicolumn{5}{|l|}{ Kreisjugendverband Hadersleben } \\
\hline 1. Jugendbund, Haderslev & 70 & 58 & 91 & 219 \\
\hline 2. Jugendbund, Rødding & & 11 & 17 & 28 \\
\hline 3. Jugendbund, S. Vilstrup & & 25 & & 25 \\
\hline \multirow{2}{*}{ 4. Jugendbund, Toftlund } & & 5 & 7 & 12 \\
\hline & & 99 & 115 & 264 \\
\hline \multicolumn{5}{|l|}{ Kreisjugendverband Sonderburg } \\
\hline 1. Jugendbund, Nordborg & 28 & 9 & 8 & 45 \\
\hline 2. Jugendbund, Augustenborg & 13 & 10 & 2 & 25 \\
\hline 3. Jugendbund, Broager & & 7 & 26 & 33 \\
\hline 4. Mädchenwanderbund, Sønderborg & 40 & 12 & & 52 \\
\hline 5. Ruderverein Germania, Sønderborg & 32 & & 170 & 202 \\
\hline \multirow[t]{2}{*}{ 6. Pfadfinderbund, Sønderborg } & 44 & 21 & 3 & 38 \\
\hline & 125 & 91 & 209 & 425 \\
\hline \multicolumn{5}{|l|}{ Kreisjugendverband Tondern } \\
\hline 1. Jugendbund, Tinglev & & 7 & 8 & 15 \\
\hline 2. Jugendbund, Jyndevad & & 8 & 12 & 20 \\
\hline 3. Jugendbund, Sæd & & 10 & 80 & 90 \\
\hline 4. Jugendbund, Bylderup & & 10 & 10 & 20 \\
\hline 5. Jugendbund, Jejsing & & 6 & 12 & 18 \\
\hline 6. Jugendbund, Ravsted & 10 & 15 & 15 & 40 \\
\hline 7. Jugendbund, N. Løgum ${ }^{1}$ & & 20 & & 20 \\
\hline 8. Jungmädchenbund, Tinglev & & 29 & & 29 \\
\hline 9. Turn- u. Spielverein, Løgumkloster ${ }^{2}$ & 10 & 20 & 8 & 38 \\
\hline 10. Wandervogel, Tønder & 18 & 41 & 2 & 61 \\
\hline 11. Kyffhäuser-Jugendgruppe, Tønder & 15 & 42 & 5 & 62 \\
\hline \multirow[t]{2}{*}{ 12. Alt-Wandervogel, Tønder } & 1 & 6 & 1 & 8 \\
\hline & 54 & 214 & 153 & 421 \\
\hline Medlemmer i alt & 373 & 534 & 574 & 1481 \\
\hline
\end{tabular}

Med betegnelsen »Børn« menes formentlig børn i den skolepligtige alder.

1. Pr. 1. november 1927.

2. Endnu ikke fuldt tilsluttet organisationen.

Kilde: Der Schleswig-Holsteiner 1928, p. 776. 
for »Deutscherhaltung der Jugend « ved skolekonsulent F. Christensen. Han skrev således om festen i 1922:

»In einer Weise war so der Tag die Probe auf den Wert der seit etwa anderthalb Jahren geleistetn Arbeit. Ich denke, die Probe ist bestanden. Welcher Aussenstehende, ja wieviele aus unserer Mitte hätten damals, als nach Ansicht jedes vernünftigen Rechners mit unzulänglichen Mitteln die Arbeit angefaßt wurde, derartiges zu hoffen gewagt? Wir haben trotz mancher Schwierigkeit im einzelnen mit unserm Führer an die deutsche Jugend Nordschleswig geglaubt.«

Artiklen afsluttes med ønsket om at Knivsbjergfesten med tiden ikke blot ville være en fest for ungdommen, men »allmählich das deutsche Volksfest Nordschleswig wür$d e \ll .{ }^{20}$

Knivsbjergfesterne illustrerede i løbet af 1920'erne, hvorledes mindretallet overvandt resignationen efter afstemningen i 1920. Fra midten af 20'erne deltog hvert år ca. 2.000 i idrætsfesten, der mere og mere antog karakter efter skolekonsulent Christensens ønske og blev en fest for den samlede tyske befolkning - »ein Volksfest «. Hvad, en »Volksfest« ikke var, blev nærmere præciseret i en større omtale af Knivsbjergfesten i 1925, der sammen med festerne i 23 og 24 var henlagt til september måned.

»Es soll keine Rummelwiese sein (note: Rummelwiese sфnderj. Rummelpot), auch nicht nur »et politisk Mфde" wie die dänische Versammlungen auf Skamlingsbanke.. En »Volksfest « betød at alle fra det tyske mindretal med udgangspunkt i »die Schiksals- und Notgemeinschaft aller Deutschen in dem an Däne- mark abgetretenen Nordschleswig, eine in den letzten Jahren immer enger gewordene Kampf- und Lebensgemeinschaft« deltog. ${ }^{21}$

Derfor var det vigtig, at idrætten indgik i Knivsbjergfesten som en del af en helhed, sådan som idrætten allerede fungerede $\mathrm{i}$ det tyske mindretal umiddelbart efter 1920:

»Genau so muß das Sportliche auf dem Knivsberg sich so in das Fest mit eingliedern, daß es nicht etwas für sich ist, sondern unbedingt in den Rahmen mit hineingehört. Dann behält alles das deutsche Gepräge. Welche Bedeutungen das Spiel für das Deutschtum und damit für das Knivsbergfest hat, können wir am besten ermessen, wenn wir uns überlegen, wie alles geworden ist in den Jahren nach der Abtretung und wie jedes Jahr wieder alles wird. Ich erinnere mich manchen fröhlichen Abends, wo deutsche Jugend auf dem Feld eines deutschen Bauern Schlagball, Tamburin- oder Faustball spielte, manche Stunde, wo mit Ernst und Eifer für ein Kreisfest oder schon führ das Knivsbergfest geübt wurde... Sport und Knivsbergfest stehen in wechselseitiger Beziehung zu einander. Das eine fördert das andere. Das Fest zieht alle Sportliebende heran, und die Art des Festes verhindert, das der Sport roh und einseitig wird. Umgekehrt gibt die spielende frische Jugend dem Fest ein gesundes, frohes und durch ihre Art ein deutsches Gepräge; denn gerade die treudeutsche Jugend kommt. ${ }^{22}$

Efter at mindretallet havde overvundet resignationen, stod det foran den opgave at formulere visioner, ønsker og politiske 
krav for den tyske ungdom og for det tyske mindretal. Talerne ved Knivsbjergfesterne gik fra midten af 1920'erne videre til end blot at formulere vigtigheden af idræt til at styrke den tyske ungdoms vilje. Imidlertid var der langt fra enighed om, hvor langt man i talerne kunne gå. Pastor SchmidtWodder, der var en gennemgående tale ved adskillelige Knivsbergfester, stod for en moderat tone, der realistisk forholdt sig til situationen efter 1920. Skulle der ske ændringer, skulle det som tidligere omtalt ske ved hjælp af stemmesedlen. I modsætning til dette demokratiske synspunkt stod det synspunkt, der argumenterede ud fra en historisk ret. En opfattelse der indirekte blev præsenteret, da den tidligere landråd - før 1920 - i Haderslev Gottfried Ernst Dryander i 1927 blev hovedtaler ved Knivsbergfesten.

Dryander blev af pastor Schmidt opfattet som en repræsentant for tidligere tiders fortyskningspolitik, og for den danske flertalsbefolkning stod han for alle de værste udslag af den preussiske voldspolitik. ${ }^{23}$ Selv om Dryander holdt en moderat tale og blot strejfede spørgsmålet om en grænserevision uanset selvbestemmelsesretten, var dette tilstrækkeligt til at uoverensstemmelserne inden for mindretallet blev åbenlyse. For at understrege sin afstandtagen fra Dryander havde pastor Schmidt ikke deltaget i Knivsbjergfesten, og efter festens afholdelse opponerede han i mindretallets presse mod, at man havde ladet en mand tale, som repræsenterede en modsat holdning, end den der nu var rådende. ${ }^{24} \mathrm{I}$ forlængelse heraf anmodede Schmidt om, at Knivsbjergselskabet fremover skulle rådføre sig med mindretallets officielle repræsentanter om valg af taler til Knivsbjergfesten.

Sagen om Dryander var ikke mindre penibel af, at det officielle Tysklands ge- sandt - Weimarrepublikkens repræsentant i København - allerede året før havde tilkendegivet i sin indberetning til Auswärtiges Amt, at $\gg . .$. enhver ved, at Knivsbjergfesten trods sportslige anstrøg legemligg $\phi r$ en agitation på dansk jord mod den danske besiddelses beståen «. ${ }^{25}$ Indberetningen var foranlediget af, at Knivsbjergselskabet $\varnothing$ nskede at iværksætte en indsamling til vedligeholdelse af Bismarcktårnet og idrætsanlægget. Udkastet til opråbet til indsamlingen var underskrevet af fremtrædende tyske embedsmænd uden at være anerkendt af det officielle Tyskland, ligesom det indeholdt en sætning om, at »Knivsbjerg skuer rundt omkring på tysk land $\ll .{ }^{26}$

I det endelige opråb var ovenævnte sætning gledet ud, ligesom en række af embedsmændenes underskrifter var fjernet. Alligevel var tonen ikke ubetinget moderat i »Aufruf zur Knivsberg-Spende«. Under turnersloganet »Jungs holt fast! « indledtes opråbet således:

»Schleswig-Holstein, der deutschen vorposten im Norden des Reiches, hat durch den Vertrag von Versailles den fünften teil seines Bodens verloren; der deutsche Kulturbesitz und das deutsche Volkstum haben sich im abgetrennten Gebiet in zäher Arbeit fest behauptet.

Pflicht jedes Deutschen ist es, dafür einzutreten, da dieser wertvolle Besitz nicht verloren geht oder geschwächt wird. Dazu bedarf es einer starken und dauernden Verbindung underer deutschen-Brüder im abgetrennten Gebiet mit dem Mutterland; sie müssen in ihrem Kampf um ihr deutsches Volkstum von dem Bewußtsein getragen sein, daß jeder deutsche mann und jede deutsche Frau im Reiche hinter ihnen stehen ...« 
Under overskriften »Knivsbergturm « fortsættes:

»Um ihn sammeln sich die Getreuen der Nordmark, an seinem Fuße feiern sie alljährlich ihre Volks- und Sportsfeste im Bekenntnis zu Stamm und Heimat. Berg und Turm sind Wahrzeichen unbesieglicher Nordmarktreue, Symbol eines steten Kampfes ... $\ll^{27}$

Selv om opråbet var blevet modereret, var der langt fra tale om en overensstemmelse med Weimar-Tysklands ønske om at stå på god fod med Danmark. Weimar-Tyskland var i det hele taget et problem for det tyske mindretal i Nordslesvig. I talerne på Knivsbjerg, samt i opråbet, henviste man enten til det tyske folk, til »stammen« eller til et Tyskland fra fortiden.

Var Weimar-Tyskland kritisk over for Knivsbjergfesterne, var den danske offentlighed det ikke mindre. Den danske presse vogtede med nidkærhed på, om festtalerne indeholdt krav om grænserevision. De danske myndigheder var dog mere bekymrede over de tilrejsende sydfra og deres nationale demonstrationer. I 1925 nægtede man at udstede fællesvisum til flere rejsegrupper fra Sydslesvig-Holsten, og det kom til en mindre paskrig mellem Danmark og Tyskland. De følgende år var man mere fleksibel, men i 1928, året efter at Dryander havde været hovedtaler, formanede myndighederne Knivsbjergselskabet om at sørge for, at deltagerne:

»... hverken på selve festpladsen eller på vejen fra denne gør sig skyldig $i$ statsfjendsk eller for befolkningen krænkende adford, at der ikke ved talernes indhold eller det $\phi$ vrigt på festpladsen forefaldende gives festen en nationalpolitisk karakter ${ }^{28}{ }^{28}$
Lige som de preussiske embedsmænd i sin tid $\varnothing$ nskede at begrænse udfoldelsen for den dansksindede del af befolkningen, greb de danske myndigheder nu ind over for Knivsbjergfesten.

\section{3-1940 \\ Kontinuitet eller brud}

Det tyske mindretals manglende accept af Weimarrepublikken rejser problemet: blev nazismens gennembrud i Tyskland af mindretallet opfattet som en kærkommen naturlig udviklingslinie fra det tidligere tyske kejserrige, som jo netop også indbefattede Nordslesvig. Flere forhold tyder på, at jordbunden i store dele af mindretallet var gødet til fordel for nazismen. I 1932 kunne en festtaler således fæste tillid til »das heimliche Deutschland, das nicht tot, sondern nur verschüttet ist $\ll .{ }^{29}$

I 1932 var nazismen imidlertid en håndgribelig størrelse, så dennes ideologi kunne udmærket have farvet festtalerens synspunkt. Et bedre belæg for kontinuitetsopfattelsen udgøres af følgende bombastiske digt, der var anbragt på forsiden af »Nordschleswig. Beiträge zum volklichen Aufbau« fra juni 1923:

\section{Wir Deutsche}

aus alle Stämmen des deutsches Volkes, aus allen Gauen des deutschen Landes, aus den Ländern der weiten Welt, sind in des Reiches Nordmarks vereint

\section{Wir bekennen}

die Qual deutscher Zerrissenheit. Wir bekennen unser aller Schicksalhafte Verbundenheit.

Wir bekennen uns zum Reich in seiner Not, dem Vorhof eines einigen Deutschlands. 
Wir glauben

an die Volksgemeinschaft, die stärker ist als Partei und Klasse.

Wir glauben an die schaffende Kraft des deutschen Herzens,

des deutschen Willens, des deutschen Geistes.

Wir glauben an das heilige Recht

auf Freiheit und Einheit Deutschlands.

\section{Wir schwören}

Die Trägheit unsrer Herzen zu brechen. Wir schwören, den Brüdern zu opfern, was wir haben und was wir sind.

Wir schwören, für das heilige Recht zu streiten

\section{Herr, mach' uns frei! ${ }^{30}$}

Digtet demonstrerer med al tydelighed den i mindretallet fremherskende konservative nationalisme. Indholdet er formet af den autoritære ånd, der herskede i årene før første verdenkrig og griber tilbage til den altyske ideologi i »Deutscher Verein für das nördliche Schleswig «. ${ }^{31}$ Som det er blevet påpeget af en af eksperterne i Sønderjyllands historie, Johan Peter Noack, var mindretallets ideologi i sin kærne næppe demokratisk. Den bundede i den tyske romantiks filosofi og var dybt frustreret af det trauma, Versailles-traktaten havde tilføjet. Der var tale om det samme åndelige substrat, som nazismen i Tyskland havde suget sin næring fra. Selv om der kan peges på forskelle mellem almindelig tysk nationalisme og nazisme, betød det historisk konkret i Nordslesvig, at det tyske mindretal intet værn havde mod nazismen. Vel er det en hård dom at fælde over det tyske mindretal i Nordslesvig, men i vurderingerne er der kun tale om nuancer, der skiller såvel tyske som danske historikere, der har beskæftiget sig hermed. ${ }^{32}$

I samtiden, hvor nazismen endnu var uproblematisk for mindretallet, udtrykte en festtaler i 1935 det på følgende måde: »Der Nationalsozialismus brauchte daher im Frühling 1933 gar nicht über die Grenze gebracht zu werden. Er war schon $d a \ll .{ }^{33}$ Også i »Festschrift zur 40-jährigen Wiederkehr des ersten Voksfest auf dem Knivsberg«, der udkom i 1934, blev den politiske udvikling syd for grænsen hilst velkommen. I en artikel »Der Sinn der Knivsbergfeste« skrev redaktør Ernst Schröder blandt andet:

»... so wirkte die Einigung der Deutschen im Frühjahr 1933, der Durchbruch der nationalen Erhebung, wie ein Signal, auszuhalten, mit Mut und Treue sich fest zu Deutschland und zum Deutschen Volk zu bekennen. Eine Hoffnung durchdrang und ermutig'e Nordschleswigs Deutschtum. Nichts gab dem so sehr Ausdruck wie das Knivsbergfest 1933, das wieder, wie so oft, Gradmesser der Kraft und Stimmung unter den Deutschen war «. ${ }^{34}$

I overensstemmelse med tidens nazistiske ånd blev »der Knivsberg « i artiklen til »einer Art Thingstätte«. Et Thingsted var ifølge oldnordisk og germansk histore et sted, hvor folkeforsamlingen eller stammen holdt møde. Betydningen af stedet var oprindelig dobbelt i den forstand, at Thingstedet var såvel et sted for afgørelsen af retslige tvister for adel og frie borger, som et sted hvor stammen udpegede sine førere samt indviede de unge stammemedlemmer til krigsførelse. ${ }^{35}$ Nazisterne introducerede $\mathrm{i}$ forbindelse med deres dyrkelse af den nordisk-germanske oldtid påny Thingsteder, hvor rituelle optog dramatiserede og dyrkede den nordisk-germanske race.

Holdningerne i det tyske mindretal nord 
for grænsen afspejlede selvfølgelig også udviklingen på den anden side af grænsen $\mathrm{i}$ det $\varnothing v r i g e$ Slesvig-Holsten, hvor højrepartier siden 1920 havde oplevet en kraftig vækst og i 1924 opnåede $48 \%$ af stemmerne. Betingelserne for nazisterne var således deciderede gunstige, fra i 1928 at have været et lille parti med $4 \%$ af de afgivne stemmer i Slesvig-Holsten fik nazisterne ved valget i $193251 \%$ af stemmerne $\mathrm{i}$ Slesvig-Holsten. I hertugdømmernes landområde erobrede nazisterne $64 \%$ af stemmerne, og i Sydslesvig alene fik partiet $62 \%{ }^{36}$

I årene fra 1933 til 1938 foregik nazificeringen af det tyske mindretal i Nordslesvig. Selvfølgelig var det ikke alle tysksindede, der blev nazister, men alle mindre- tallets organisationer endte med at blive kontrolleret af nazister. Imidlertid var der intern rivalisering om, hvem der skulle lede mindretallet. Pastor Schmidt fors $\emptyset$ gte uden succes at fastholde sin lederposition, og frem til 1938 kæmpede Deutsche Arbeiterpartei Nordschleswig, forkortet NSDAP-N, med Nationalsozialistische Arbeitsgemeinschaft Nordschleswig om magten. Sidstnævnte tabte, og fra 1938 stod NSDAP-N med magten; førerskikkelsen blev dyrlæge Jens Möller fra Gråsten. ${ }^{37}$ Ved sin side fik han den tidligere omtalte oberleutnant Peter Larsen, der stod for den praktiske organisering af nazismen. For pressetjenesten - propagandakontoret - stod lærer Asmus Wilhelm Jürgensen, der ofte skrev under navnet Asmus von der Heide.

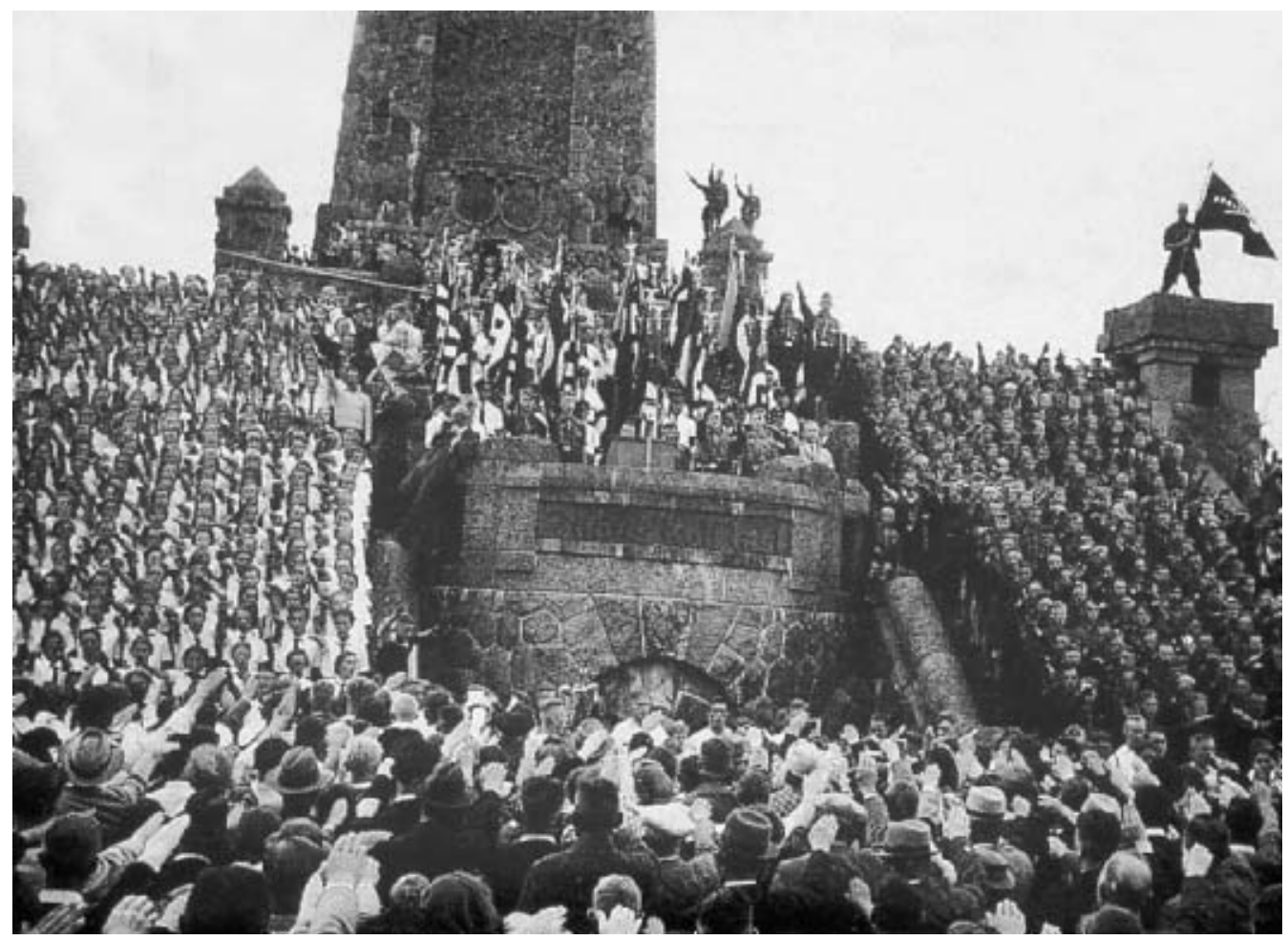

Knivsbjergfesten efter Hitlers magtovertagelse i 1933 (fra Der Knivsberg, 1994). 
I 1933 oplevede man i begejstring over »das neue Deutschland« en større tilstrømning til Knivsbjergfesten. Op til 10.000 deltog ifølge mindretallets egen presse, noget mindre ifølge dansk presse, men en vækst i deltagerantallet var der tale om. Som det fremgår af billeder fra samtiden, omkransede hagekorsflaget straks fra 1933 folkefesten ved Knivsbjerg. For ungdommen talte Hans Berg, der senere faldt som tysk soldat under anden verdenskrig. ${ }^{38} \mathrm{I}$ 1934 talte den moderate Pastor Schmidt, der dog senere sluttede op bag Jens Möller, han sagde blandt andet: „Das deutsche Volk hat wieder einen Führer, auf dessen Tatkraft und Klugheit es unbedingt vertraut $\ll .{ }^{39}$

De kommende år var Knivsbjergfesterne prægede af mindretallets interne uoverensstemmelser, tilsyneladene sikrede idrætsudfoldelsen dog, at festen blev afholdt. I 1935 udspillede der sig ved Knivsbjergfesten i juni ved tårnets fod en såkaldt »Sängerkrieg «, hvor to rivaliserende partigrupper fors $\varnothing$ gte at overd $\varnothing$ ve hinanden. ${ }^{40}$ I 1936 var uoverensstemmelserne i mindretallet så store, at man ikke kunne enes om, hvem der skulle være festtaler, og festen blev flyttet til efteråret som en ren idrætsfest.

I 1937 var den interne rivalisering endnu ikke afsluttet. Ungdommen samlede sig fra 1937 dog mere og mere om det rent nazistiske tidsskrift »Junge Front - herausgegeben von der deutschen Jugend Nordschleswig.« Nummer 1 udkom i marts 1937 og havde som logo på forsiden hagekorset over Knivsbjergtårnet (se billede), et logo der blev anvendt frem til april 1939. Formanden for Deutsche Jugendwerk Carl Tönder, der egentlig var forholdsvis moderat i sine synspunkter, indledte det første nummer med ønsket om, at Junge Front kunne »eintreten für eine vorbildliche, nationalsozialistische Haltung jedes Einzel-

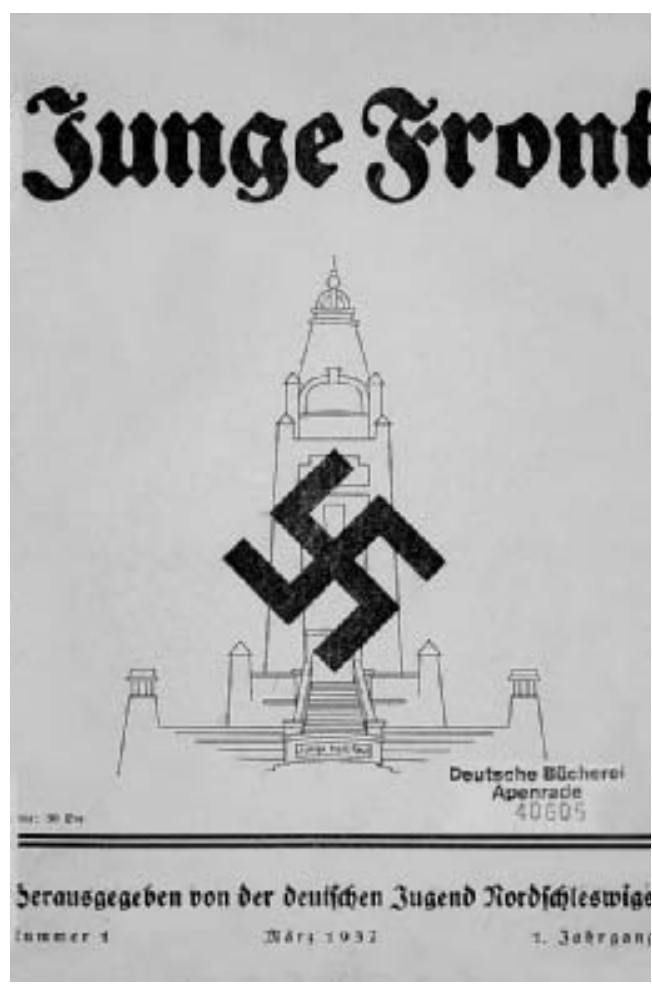

Forsiden fra Junge Fronts forste nummer 1937.

nen ${ }^{41}$ Skribent i det første nummer var også formanden for »Bund für Leibesübungen « Peter Pedersen, der udtrykte det $\varnothing$ nske at:

$»$... jedes Mietglied eines deutschen Turn- oder Sportvereins die Ueberzeugung in sich trägt, da es eine für das Volkstum notweindige Arbeit zu leisten hat und mit verantwortlich ist für die Gestaltung der Zukunft unserer Volksgruppe, dann dürfen wir sagen: »Wir sind auf dem richtigen Wege ${ }^{42}$

I 1938 sluttede såvel Carl Tönder som Peter Pedersen op bag Jens Möller.

Knivsbjergfesten i 1937 forløb uden åbne interne uoverensstemmelse, det sam- 
me var tilfældet for festen i 1938. Knivsbjergfesten i 1939 blev den første fest efter den etablerede enighed bag »føreren« for NSDAP-N Jens Möller, og der var stillet store forventninger til såvel folkefesten som til Möllers festtale. Hitlers indlemmelsespoltik og Østrigs »anschluß« lagde naturligt op til et $\varnothing$ nske fra de tysksindede nordslesvigere om at komme »heim ins Reich«. Problemet var imidlertid, at en grænserevision ikke indgik i Berlins politik, tværtimod ønskede man at bevare et godt forhold til de skandinaviske lande. Efter i foråret 1939, som repræsentant for mindretallet, at være blevet indvalgt i det danske folketing, fik Jens Möller i Berlin besked om, at han i sin første tale i folketinget ikke måtte komme ind på grænsespørgsmålet. Dette skete samtidig med, at man forhandlede om en ikke-angrebspagt mellem Danmark og Tyskland. ${ }^{43}$

Ordren fra Berlin voldte helt oplagt problemer for Jens Möller, der nu var såvel parti- som mindretalsfører, da han den 25. juni skulle tale ved Knivsbjergfesten, hvor Deutsche Jugendschaft Nordschleswig stod for turnen og anden idræt, medens Deutsche Mädenschaft Nordschleswig fremviste »Körperschule $«{ }^{44}$ I sin tale betegnede Möller grænsedragningen i 1920 som ulykkelig og formulerede sin forhåbning til »das Großgermanische Reich« - på den anden side var NSDAP-N »keine Grenzverschieber $\ll .{ }^{45}$

Udtalelserne var imidlertid tilstrækkelige til, at Möller af den tyske gesandt i København fik tildelt en mild reprimande. I den danske presse blev formuleringerne om grænsedragningen i 1920 opfattet som en fornærmelse og som udtryk for »Knivsbjergfanatisme «. I juli-nummeret tog »Junge Front « til genmæle mod den danske presse:
»Wieweit eine sachliche, ruhige Darstellung von Tatsachen »Fanatismus « sein kann, ist uns Deutschen schleierhaft. Wir haben nur eine Erklärung dafür, und die heißt: Fanatismus und Wahrheitsliebe ist bei einem gewissen Teil der dänischen Publizisten ein und dasselbe. Aus der selben Einstellung heraus haben sie ja Adolf Hitlers große Reden als Fanatismus bezeichnet. Unter diesen Umständen soll man uns ruhig Fanatiker nennen ${ }^{4}{ }^{46}$

Det var blandt andet de unges forventninger til Stortyskland, der havde fået Jens Möller til at trodse ordren fra Berlin. Til den tyske konsul i Aabenraa forklarede han, at han var nødt til at have handlefrihed i Nordslesvig, og at udtalelserne i Knivsbjerg var fremsat for at få folketyskerne til at holde ud; thi hvad skulle han sige til ungdommen. ${ }^{47}$

Netop ungdommens forhåbninger om en grænserevison, som NSDAP-N's ledere selv havde næret, fik afgørende betydning for Knivsbjergfesterne de kommende år - i den forstand at de ikke blev afholdt. For definitivt at skabe ro om grænsespørgsmålet i Nordslesvig undstregede Hitler i sin rigsdagstale den 6. oktober 1939, at der ikke fra tysk side var rejst krav om en ændring af den dansk-tyske grænse, selv om den var fastsat ved Versaillesfreden. ${ }^{48}$ En opfattelse Berlin også fastholdt, efter at tyske tropper den 9. april 1940 rykkede ind $\mathrm{i}$ Danmark. I mindretallet førte dette til, at Jens Möller og Peter Larsen umiddelbart efter den 9. april til politiet i Aabenraa erklærede deres loyalitet over for den danske stat.

Flere i det tyske mindretal accepterede dog ikke Hitlers politik på grænseområdet, især lederen af NSADP-N's pressekontor, 


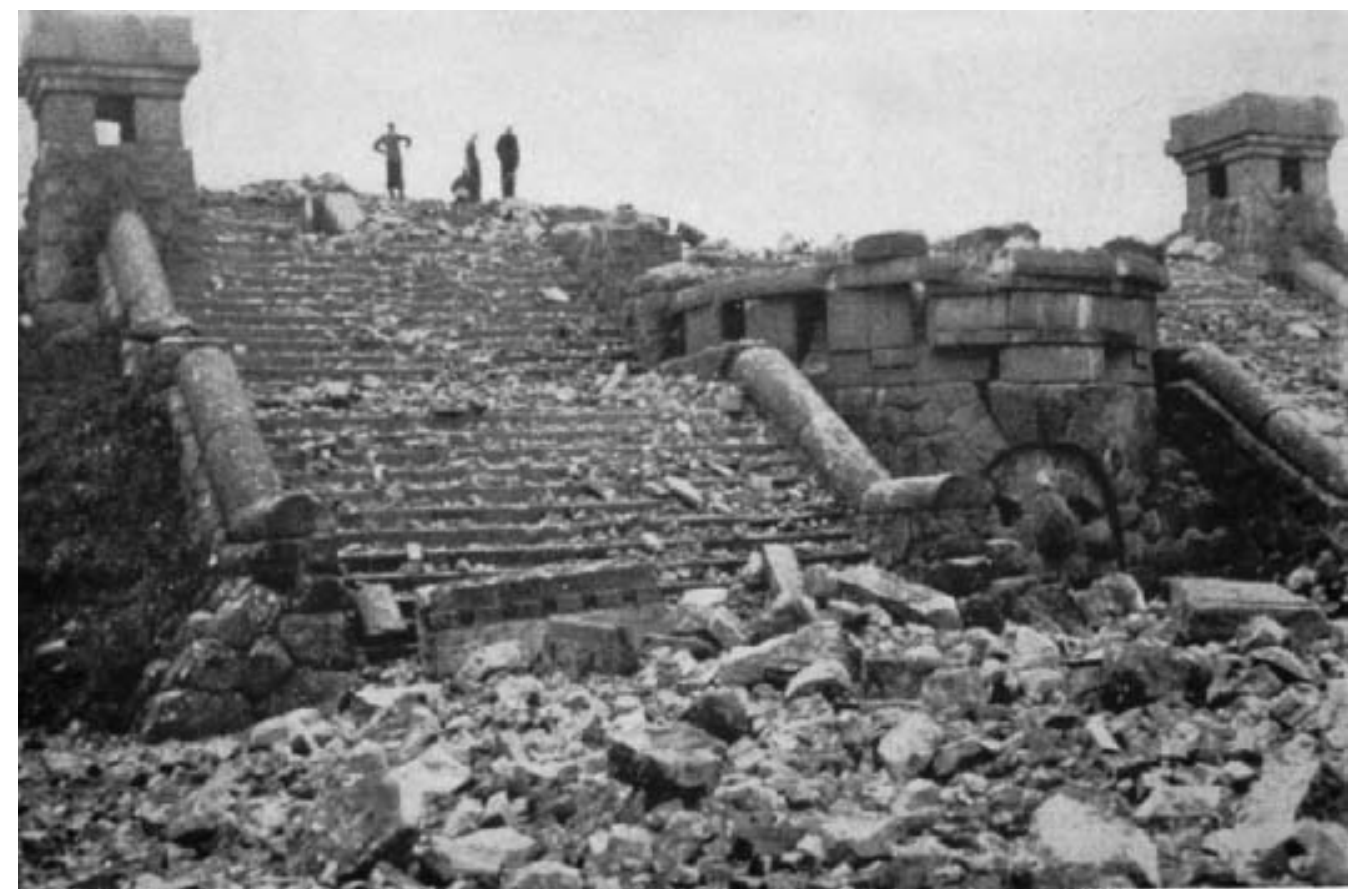

Det фdelagte Knivsbjergtårn 1945 (fra Lorenz Rerup, Slesvig og Holsten efter 1830).

den ekstreme nazist $\gg$ Asmus von der Heide«, fyldte spalte op og ned i Junge Front med »Blut und Boden «-krav og grænserevisionsønsker. I april-nummeret af Junge Front, der udkom efter »Der denkwürdige 9. April «, analyserede Asmus von der Heide »20 Jahre deutsche Volksgruppe in Nordschleswig«, artiklen sluttede som følger:

$\gg$ Am 23. Juni wird die deutsche Volksgruppe auf dem Knivsberg ihre große Heerschau abhalten. Zwanzig Jahren nach der Trennung vom Reich soll sie hier nach außen ihre Kraft und ihren Umfang zeigen ... Mann für Mann werden wir künden, wie nie zuvor von unausrottbarem, lebendigem deutschen Volk auf Schleswigs, auf unserer Heimat heiliger Erde. $\ll^{49}$
Knivsbjergfesten i 1940 blev aldrig gennemført. Heller ikke de kommende år under besættelsen blev der afholdt Knivsbjergfester. Den 16. august 1945 - godt tre måneder efter Danmarks befrielse - blev granittårnet og festpladsen $\varnothing$ delagt ved sprængning af danske sabotører, der i et opgør med tyskheden én gang for alle ønskede at destruere $» k u l t s t e d e t \ll$. En handling, der siden blev fordømt af den danske statsminister Hans Hedtoft. ${ }^{50}$

I 1949 bekostede den danske stat en delvis reetablering af Knivsbjerg, der fra 1947 påny kom til at fungere som mødested for det tyske mindretals kulturelle aktiviteter. Også efter anden verdenskrig er det især idrætten, der er blevet tillagt betydning for kontinuiteten i mindretallets aktiviteter. $^{51}$ 


\section{Noter}

1. Se Jørn Hansen, »Idræt i grænselandet. Turner og gymnaster I Nord- og Sydslesvig. Fra »Vormärz« frem til delingen i 1920 « I: Idratshistorisk Årbog 1997 (Odense Universitetsforlag 1998), pp. 9-34.

2. Se Uwe Heldt, 125 Jahre Turn- und Sportbund Flensburg. Eine Beitrag zur Entwicklung von Turnen und Sport in Flensburg (Kleine Reihe der gesellschaft für Flensburg Stadtgeschichte Heft 21, Bd. 1 1991), p. 167. Lorenz Rerup, Slesvig og Holsten efter 1830 (Politikens Forlag, København, 1982), pp. 191-92.

3. Heldt p. 165.

4. Se Gottlieb Japsen (ed.), Dansk og tysk i Sønderjylland (Gyldendal København 1979).

5. ibid pp. 34-36.

6. Olaf Peters, »Weihnachten, Ostern und Knivsbergfest «. 100 Jahre »Deutsches Volksfest « auf dem Knivsberg. I: Jürgen Ostwald (Hrsg), Der Knivsberg. 100 Jahre deutsche Versammlungsstätte in Nordschleswig (Westholsteinische Verlagsanstalt Boysens \& Co, Heide, 1994), p. 66.

7. Ibid p. 60.

8. Heldt opus cit p. 165.

9. Inge Adriansen, Fadrelandet, folkeminderne og modersmålet (Skrifter fra Museumsrådet for Sønderjyllands Amt. Sønderborg 1990) p. 178.

10. Ibid.

11. Olaf Peters opus cit p. 65.

12. Ibid p. 82.

13. Se G. Japsen Den fejlslagne germanisering. Den tyske forening for det nordlige Slesvig - Bidrag til det tyske mindretals historie efter 1864 (Skrifter, udgivet af Historisk Samfund for Sønderjylland, nr. 57, Åbenrå, 1983).

14. Se Henrik Becker-Christensen, Det tyske mindretal i Nordslesvig 1920-1932 (Institut for Grænseregionsforskning, Aabenraa, 1990) Volume 1, p. 250.

15. Se Fr. Christensen, »Aufbau deutscher Schulen in Nordschleswig 1919-1940« I: Schriften für Heimatkundlichen Arbeitsgemeinschaft für Nordschleswig (1971) h. 24, p. $114 \mathrm{ff}$.

16. Se Olaf Peters opus cit p. 83.

17. Se Harboe Kardel, Fünf Jahrzehnte in Nordschleswig. Ein Beitrag zur Geschichte der politischen Organisationen der deutschen Volksgruppe in der Zeit von 1920 bis 1970 (Verlag der Heimatkundlichen Arbeitsgemeinschaft in Apendrade. Heft 22 1971). Becker-Christensen opus cit. pp. 250-51.

18. Becker-Christensen p. 253.
19. Se Nordschleswig. Beiträge zum volklichen Aufbau, 1. heft (1922, Nordmark Verlag Tondern und Kiel), p. 8.

20. Se Nordschleswig. Beiträge zum volklichen Aubau, 2. heft 1922, pp. 79-82.

21. Se Nordschleswig. Beiträge zum volklichen $A u$ bau, Sonderheft, »Deutsche Jugend Knivsbergfest (1925), p. 103.

22. Anna Wernich, »Spiel und Sport auf dem Knivsberg«, ibid pp. 105-106.

23. Becker-Christensen opus cit p. 134.

24. Ibid p. 135.

25. Gerhard von Mutius ifølge Becker-Christen p. 270.

26. Ibid p. 271.

27. »Aufruf zur Knivsberg-Spende« gengivet i Franz Lubowitz, »Der Knivsberggesellschaft« I: Jürgen Ostwald (Hrsg), Der Knivsberg. 100 Jahre deutsche Versammlungsstätte in Nordschleswig, opus cit pp. 39-41.

28. Becker-Christensen opus cit p. 272.

29. Festrede Petersen, Nordschleswigsche Tageszeitung, 27. juni 1932, ifølge Olaf Peters opus cit p. 86.

30. Se Nordschleswig. Beiträge zum volklichen $A u$ bau, 3. heft (1923).

31. G. Japsen, Den fejlslagne germanisering, opus cit p. 243.

32. Se Johan Peter Noack, Det tyske mindretal $i$ Nordslesvig under besæettelsen (Dansk Udenrigspolitisk Instituts Skrifter 1974), p. 19. Olaf Peters opus cit p. 86 og Harboe Kardel opus cit.

33. Olaf Peters p. 86.

34. Se Julius Kähler (Hrsg.), Festschrift zur 40jährigen Widerkehr des ersten Volkfestes auf dem Knivsberg (Apenrade 1934), p. 45.

35. Horst Ueberhorst, »Leibesübungen bei den Germanen« I: Horst Ueberhorst, Geschichte der Leibesübungen 3 Teilband 1 Leibesübungen und Sport in Deutschland von den Anfängen bis zum Ersten Weltkrieg, Verlag Bartels \& Wernitz (Berlin, 1980), p. 26.

36. Harboe Kardel opus cit. p. 106.

37. Se J. P. Noack opus cit og Harboe Kardel opus cit 38. Harboe Kardel p. 134.

39. Ibid og Olaf Peters opus cit p. 88.

40. Harboe Kardel p. 146.

41. Junge Front, Herausgegeben von der deutschen Jugend Nordschleswig, nummer 1 (1937), p. 3.

42. Ibid p. 13 . 
43. J. P. Noack opus cit p. 31 og Harboe Kardel opus cit p. 170.

44. Se P. J. Sönnichsen, Spiegel der Jahre »Der deutsche Volkskalender für Nordschleswig " Eine Kulturgeschichte der deutschen Volksgruppe in Dänemark (Deutscher Schul- und Sprachverein für Nordschleswig 1994), p. 284.

45. Harboe Kardel opus cit p. 170 og Olaf Peters opus cit p. 91.

46. Junge Front, nummer 7 (1939), p. 13.

47. J. P. Noack opus cit p. 22.

48. Ibid p. 33
49. Junge Front, nummer 4 (1940), p. 10.

50 . Se »Die Sprengung des Knivbergturmes. Dänischer Widerstandskämpfer und deutsche Anwohner berichten. Zusammengestellt und erläutert von Inge Adriansen und Immo Doege« I: Jürgen Ostwald (Hrsg), Der Knivsberg. 100 Jahre deutsche Versammlungsstätte in Nordschleswig, opus cit pp. 197-206 samt L. J. H. Zierau, Schweinhund (Frederiksberg 1993), pp. 157-179.

51. Se hertil Lorenz Rerup, Slevig og Holsten efter 1830, opus cit., samt Inge Adriansen opus cit. 